\title{
Renal Light Chain Deposition Associated with the Formation of Intracellular Crystalline Inclusion Bodies in Podocytes: A Rare Case Report
}

\author{
Yuan-da Wang ${ }^{1}$, Zhe-yi Dong ${ }^{1,2}$, Xue-guang Zhang ${ }^{1}$, Wei Zhang ${ }^{1}$, Zhong Yin ${ }^{1}$, \\ Qiang Qiu ${ }^{1}$ and Xiang-mei Chen ${ }^{1}$
}

\begin{abstract}
We herein report the case of an elderly woman with bone pain and proteinuria as the main clinical manifestations. The patient was diagnosed with the IgG $\kappa$ type of multiple myeloma. Her renal pathology consisted of widespread $\kappa$ light chain protein deposition associated with the formation of large quantities of rodlike crystals in podocytes. This phenomenon is very rare. We explored the significance of this crystal formation via a detailed and descriptive analysis and also performed a literature review, thus providing data to increase the available information about this type of disease.
\end{abstract}

Key words: crystalloid, podocyte, multiple myeloma, nephropathy

(Intern Med 55: 369-373, 2016)

(DOI: 10.2169/internalmedicine.55.4443)

\section{Introduction}

Myeloma nephropathy is the most common and serious complication of multiple myeloma. Malignant plasma cells secrete large amounts of immunoglobulin at a rate of 8-35 $\mathrm{g} /$ day (the normal rate is $0.9 \mathrm{~g} /$ day) (1) and these light chain proteins are deposited in various forms, including casts, fibres, granules and crystalloids, causing constant damage to the kidney parenchyma and corresponding clinical pathological manifestations (2). Deposition in the form of crystalloids is not common and deposition in podocytes represents the rarest form of crystal deposition. Among the types of renal damage caused by monoclonal light chains, $70 \%$ of these are renal tubular damage and approximately $30 \%$ are glomerular injury (1). Additionally, there may also be more than one type of damage.

\section{Case Report}

The patient was a 71-year-old woman who was admitted due to mild oedema of the eyelid and bilateral lower ex- tremities with associated abnormal urinalysis findings for 1 month. Occasional blurred vision and headaches were noticed 1 month prior to admission. She was diagnosed to have hypothyroidism 6 years prior and given oral levothyroxine sodium therapy. The patient had no history of hypertension or diabetes mellitus. Her physical examination revealed a blood pressure of $140 / 90 \mathrm{mmHg}$ and a body mass index (BMI) of $28.4 \mathrm{~kg} / \mathrm{m}^{2}$. There were no pathological heart murmurs and no dry or moist rales. Her eyelids and lower extremities demonstrated mild oedema.

Laboratory studies showed a haemoglobin level of $109 \mathrm{~g} /$ $\mathrm{L}$, normal white blood cells and platelets, albumin of 36.3 $\mathrm{g} / \mathrm{L}$, total protein of $94.9 \mathrm{~g} / \mathrm{L}$, serum creatinine of $0.9 \mathrm{mg} /$ $\mathrm{dL}$, blood calcium of $2.29 \mathrm{mmol} / \mathrm{L}$, blood $\mathrm{IgG}$ of $3,220.0$ $\mathrm{mg} / \mathrm{dL}(700-1,600 \mathrm{mg} / \mathrm{dL}), \kappa \mathrm{Ig}$ light chain of $1,050.0 \mathrm{mg} /$ $\mathrm{dL}(170-370 \mathrm{mg} / \mathrm{dL}), \lambda$ Ig light chain of $59.0 \mathrm{mg} / \mathrm{dL}(90-$ $210 \mathrm{mg} / \mathrm{dL}$ ), urine specific gravity of 1.010 , urinary microalbumin of $63.6 \mathrm{mg} / \mathrm{dL}(0-3 \mathrm{mg} / \mathrm{dL})$, urinary $\beta 2$ microglobulin of $0.02 \mathrm{mg} / \mathrm{dL}(0-0.02 \mathrm{mg} / \mathrm{dL})$, urine $\mathrm{IgG}$ of $20.7 \mathrm{mg} / \mathrm{dL}(0-$ $0.96 \mathrm{mg} / \mathrm{dL})$, urine $\mathrm{K}$ Ig light chain of $20.9 \mathrm{mg} / \mathrm{dL}(0-0.79$ $\mathrm{mg} / \mathrm{dL})$, and urine $\lambda$ Ig light chain of $0.492 \mathrm{mg} / \mathrm{dL}(0-0.43$ $\mathrm{mg} / \mathrm{dL}$ ). Her urinary protein level was $3^{+}$with negative urine

${ }^{1}$ Department of Nephrology, Chinese PLA General Hospital, Chinese PLA Institute of Nephrology, State Key Laboratory of Kidney Diseases, National Clinical Research Center of Kidney Diseases, China and ${ }^{2}$ Department of Nephrology, Chinese PLA 309 Hospital, China Received for publication November 4, 2014; Accepted for publication February 24, 2015 Correspondence to Dr. Qiang Qiu, medsage@126.com 


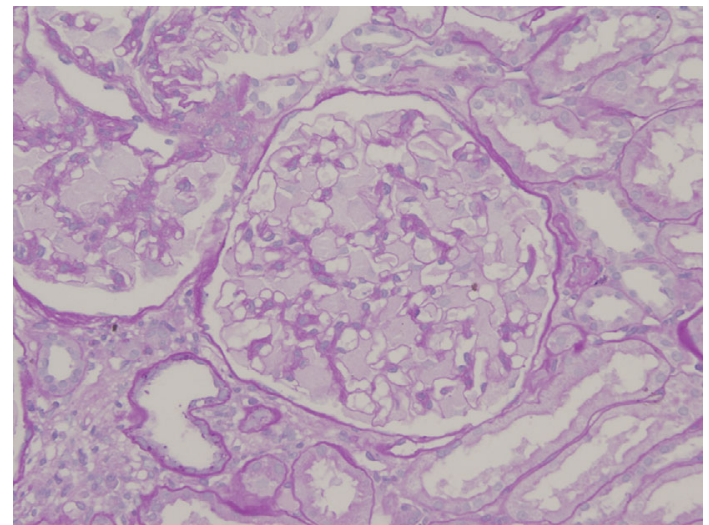

Figure 1. Podocytes were swollen with large amounts of protein particles lightly stained with PAS in the cytoplasm (Original magnification $\times 400$ ).

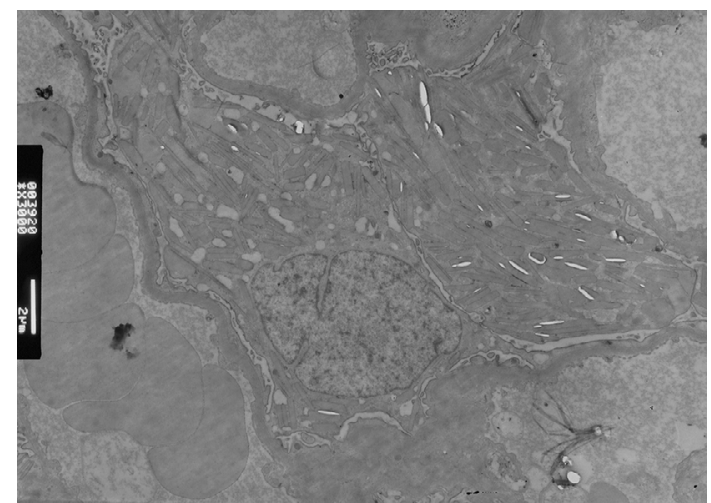

Figure 3. Large quantities of rod-like crystals visible in podocytes (Electron microscopy, original magnification $\times 3,000)$.

occult blood findings. The 24-hour urinary protein quantification was $2.13 \mathrm{~g}$. The size of the left kidney was $11.8 \times$ $4.3 \times 5.4 \mathrm{~cm}$, with a parenchymal thickness of $1.3 \mathrm{~cm}$. The size of the right kidney was $10.8 \times 4.7 \times 4.1 \mathrm{~cm}$, with a parenchymal thickness of $1.4 \mathrm{~cm}$ and a slightly stronger echo in the cortex. Bone marrow aspiration was conducted to perform immunophenotyping; the results revealed $27.2 \%$ abnormal plasma cells and a diagnosis of $\kappa$ IgG multiple myeloma of Durie-Salmon (DS) stage IB and International Staging System (ISS) stage II.

\section{Renal biopsy findings}

A small portion of renal cortical tissue was provided for an analysis. On a light microscopy examination, 10 complete glomeruli were identified. All of them had a normal glomerular volume. One glomerulus was globally sclerotic (10\%). There were no glomerular adhesions, no segmental glomerulosclerosis, or crescent formation. The glomeruli did not show mesangial cell proliferation or mesangial matrix widening, but some capillary loops showed poor opening. Additionally, the Bowman's capsule did not show thickening or stratification, but the podocytes were swollen with large amounts of protein particles that were stained with Periodic

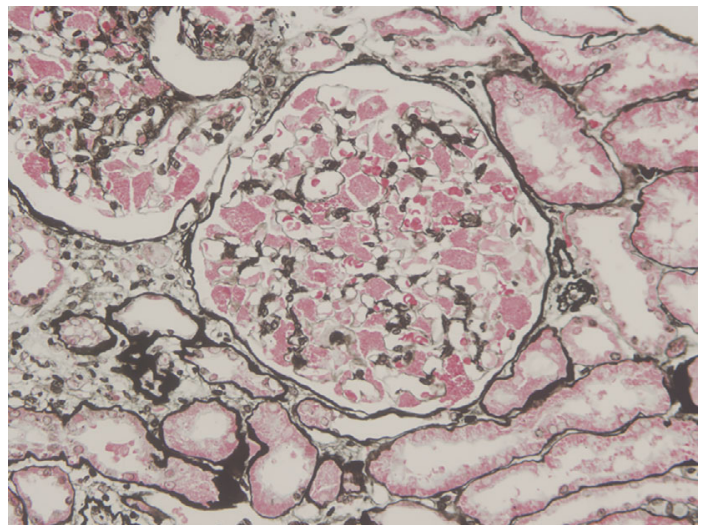

Figure 2. PAM showed large quantities of protein particles stained in red in the cytosol of glomerular podocytes (Original magnification $\times 3,000$ ).

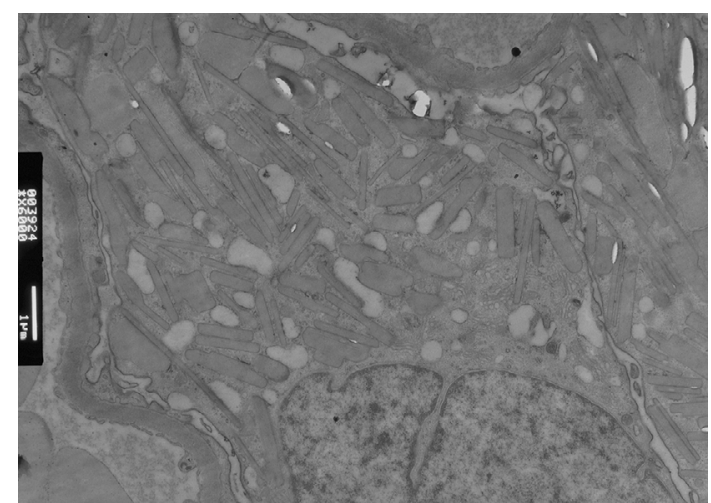

Figure 4. Podocytes contain rod-like crystals (Electron microscopy, original magnification $\times \mathbf{6 , 0 0 0})$.

acid-Schiff (PAS) in the cytoplasm (Fig. 1). There was severe interstitial fibrosis with tubular atrophy and granular degeneration of the epithelial cells. The intrarenal artery showed intimal thickening ( $>$ media thickness). Periodic acid methenamine silver (PAM) (Fig. 2) and Masson's staining showed large quantities of protein particles lightly stained in red in the cytosol of glomerular podocytes and tubular epithelial cells. The basement membrane was not thick and there were no double-track signs or spikes. The immunofluorescence results were as follows: $\operatorname{IgG}(-), \operatorname{IgA}(-)$, IgM (-), C3 (-), C4 (-), C1q (-), and Fib (-). Electron microscopy showed large quantities of rod-like crystals visible in podocytes (Fig. 3,4), while not in tubular epithelial cells. Immunohistochemistry showed the cytoplasm of podocytes was positively stained for $\kappa$ light chain. The $\kappa$ light chain was also positively stained inside the tubular epithelial cells, mainly in the proximal tubules (Fig. 5, 6). The pathological diagnosis was multiple myeloma with kidney damage.

\section{Clinical follow-up}

The patient received PD (bortezomib, dexamethasone) and VMP (bortezomib, melphalan, and prednisone) chemotherapy. Lab reexaminations showed that the 24-hour urinary protein level was $0.3 \mathrm{~g}$, creatinine was $75.8 \mu \mathrm{mol} / \mathrm{L}$, IgG 


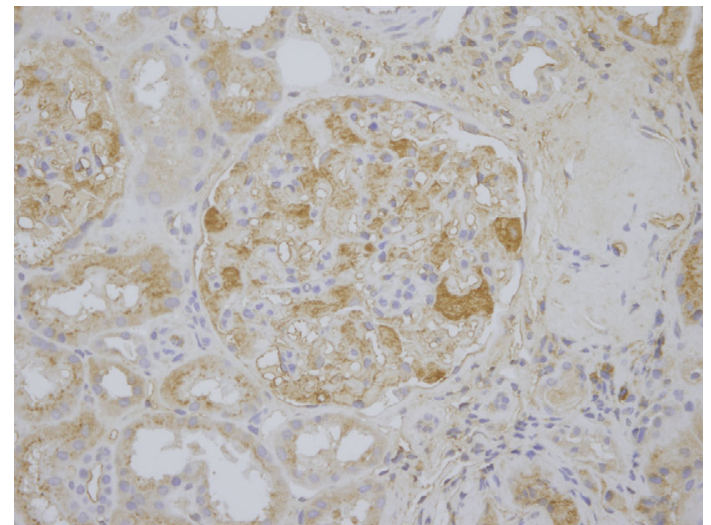

Figure 5. Cytoplasm of podocytes was positively stained for $\kappa$ light chain (Immunohistochemistry, original magnification $\times 400$ ).

was $1,470 \mathrm{mg} / \mathrm{dL}$, $\kappa$ Ig light chain was $326 \mathrm{mg} / \mathrm{dL}$, and $\lambda \mathrm{Ig}$ light chain was $76.9 \mathrm{mg} / \mathrm{dL}$. Throughout the follow-up period, the patient's creatinine level remained normal, with no upward trend.

\section{Discussion}

Kidney damage is a common complication of multiple myeloma. The incidence of proteinuria is $88 \%$ and that of renal failure is slightly lower at $22-56 \%(3,4)$. The most common type of renal parenchymal damage caused by multiple myeloma is cast nephropathy, followed by amyloidosis, light chain deposition disease, and proliferative glomerulonephritis.

The patient's renal pathology showed extensive light chain deposition, but there were no changes to the mesangial nodules characteristic of light chain deposition disease. Immunohistochemistry showed extensive $\kappa$ light chain deposition in the podocytes and renal tubular epithelial cells. Although the patient presented with renal tubular $\kappa$ light chain deposition, the patient did not show any manifestations related to renal tubular injury. Her urine specific gravity was normal. Although a urine osmolality examination was not performed, the patient did not present urine concentration disorders, such as nocturia. In addition to a significantly increased discharge of light chain protein, the urine concentrations of large proteins, such as albumin, were also significantly increased, whereas the discharge of small proteins, such as $\beta 2$-microglobulin, was normal, suggesting that the renal damage caused by crystalloid formation and light chain deposition mainly occurred in the podocytes. Both immunofluorescence and immunohistochemistry techniques could locate light chain deposition in tubules. Immunofluorescence is more suitable for identifying the location of membrane proteins, while immunohistochemistry is more suitable for location of cytoplasm protein. The immunopathology results of Nasr et al. (5) and Kowalewska et al. (6) revealed negative $\kappa$ light chain immunofluorescence but positive immunohistochemical staining in paraffin-embedded

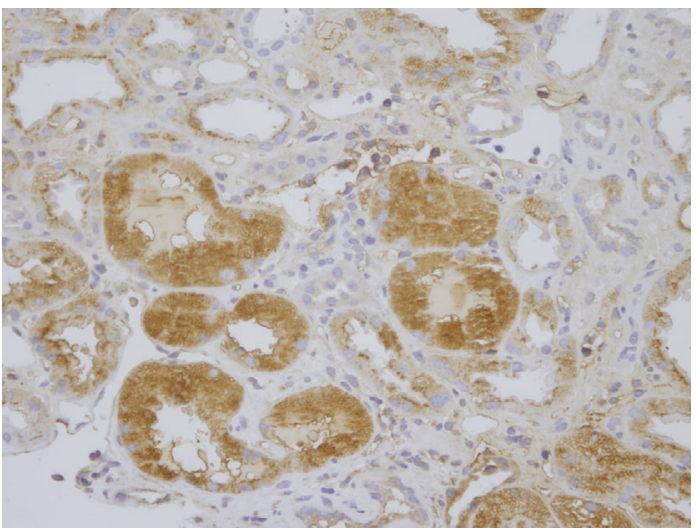

Figure 6. $\kappa$ light chain was positive inside of the tubular epithelial cells, mainly in the proximal tubules (Immunohistochemistry, original magnification $\times \mathbf{4 0 0}$ ).

tissues, suggesting that immunohistochemistry was more sensitive for the detection of intracellular crystalline deposition. The reason for these findings may be that antigen retrieval promotes degeneration of the cell membrane or lysosomes or that open epitopes may be hidden inside the crystal lattice. Therefore, we only conducted $\kappa$ light chain immunohistochemistry. We found that the cytoplasm of podocytes was positive for $\kappa$ light chain staining and positive $\kappa$ light chain staining was also observed inside of renal tubular epithelial cells, mainly in the proximal tubule. Immunohistochemistry and immunofluorescence techniques have limitations for the diagnosis of light chain deposition disease in the form of crystalloids because they cannot determine the relationship between monoclonal light chain deposition and crystal structure, whereas immunoelectron microscopy techniques can provide information on this immunomorphological association. Kapur et al. detected light chain crystal formation within lysosomes using immunoelectron microscopy (7). Unfortunately, the equipment and technology required for immunoelectron microscopy are not popular because of their high cost and complexity. Although it is not recommended as a routine examination method, immunoelectron microscopy can facilitate confirmation of the diagnosis in specific cases (8).

There are various forms of light chain deposition, including the deposition of casts, fibres, granules, and crystalloids (9). Crystal formation is less common and can be deposited inside cells, such as renal tubular epithelial cells and malignant plasma cells, or on the outside of cells. Larsen et al. (10) studied 10,081 cases of renal biopsy specimens and found that there were only 13 cases of proximal tubular damage caused by light chain proteins, including 3 cases with crystalloid formation ( 2 of 3 cases showing $\kappa$ light chains). In this previous study, the diagnosis of malignant plasma cells could not be established for some patients at the time of renal biopsy, although the patients were diagnosed later in a follow-up study with the gradual emergence of corresponding clinical manifestations (10). In contrast, it is very rare to present large quantities of crystalline inclu- 
Table. Main Features of Eleven Cases of Crystalloid Inclusions in Podocytes (5).

\begin{tabular}{|c|c|c|c|c|}
\hline Reference & Sex/age(years) & Clinical feature & Location of crystals & $\begin{array}{l}\text { Kind of light chain in } \\
\text { podocytes }\end{array}$ \\
\hline 2 & Male/56 & Acute renal failure & $\begin{array}{l}\text { Podocytes, tubular epithelial } \\
\text { cells, interstitial } \\
\text { macrophages, tubular lumina }\end{array}$ & IF: Negative for both $\kappa$ and $\lambda$ \\
\hline 5 & Female/54 & $\begin{array}{l}\text { Renal insufficiency, } \\
\text { nephrotic syndrome }\end{array}$ & $\begin{array}{l}\text { Proximal tubular epithelial } \\
\text { cells, podocytes, tubular casts }\end{array}$ & $\begin{array}{l}\text { IF: Negative for both } \kappa \text { and } \lambda \\
\text { IHC: Positive for } \kappa \text { and } \\
\text { negative for } \lambda\end{array}$ \\
\hline 6 & Female/52 & $\begin{array}{l}\text { Renal insufficiency, } \\
\text { mild proteinuria }\end{array}$ & $\begin{array}{l}\text { Podocytes, parietal epithelial } \\
\text { cells; tubular epithelial cells, } \\
\text { interstitial monocytes }\end{array}$ & $\begin{array}{l}\text { IF: Negative for both } \kappa \text { and } \lambda \\
\text { IHC: Positive for } \kappa \text {; negative } \\
\text { for } \lambda\end{array}$ \\
\hline 11 & Male/45 & $\begin{array}{l}\text { Acute kidney injury, } \\
\text { nephrotic syndrome }\end{array}$ & $\begin{array}{l}\text { Podocytes, mesangial cells, } \\
\text { tubular epithelial cells }\end{array}$ & $\begin{array}{l}\text { IF: Positive for } \kappa \text {; negative } \\
\text { for } \lambda\end{array}$ \\
\hline 12 & Male/53 & $\begin{array}{l}\text { Renal insufficiency, } \\
\text { proteinuria }\end{array}$ & $\begin{array}{l}\text { Podocytes, tubular epithelial } \\
\text { cells }\end{array}$ & $\begin{array}{l}\text { IF: Positive for } \kappa \text {; negative } \\
\text { for } \lambda\end{array}$ \\
\hline 13 & Male/57 & $\begin{array}{l}\text { Renal insufficiency, } \\
\text { subnephrotic } \\
\text { proteinuria }\end{array}$ & $\begin{array}{l}\text { Podocytes, mesangial cells, } \\
\text { parietal epithelial cells, } \\
\text { tubular epithelial cells }\end{array}$ & IF: Negative for both $\kappa$ and $\lambda$ \\
\hline 14 & Male/71 & Proteinuria & $\begin{array}{l}\text { Interstitial histiocytes, } \\
\text { podocytes, parietal epithelial } \\
\text { cells }\end{array}$ & $\begin{array}{l}\text { IHC: Positive fork and } \lambda \\
\text { heavy chain (performed on } \\
\text { the cornea) }\end{array}$ \\
\hline 15 & Female/40 & $\begin{array}{l}\text { Nephrotic } \\
\text { syndrome, renal } \\
\text { failure }\end{array}$ & $\begin{array}{l}\text { Podocytes, parietal epithelial } \\
\text { cells, tubular epithelial cells, } \\
\text { tubular lumina }\end{array}$ & $\begin{array}{l}\text { IHC: Positive for } \kappa \text {; negative } \\
\text { for } \lambda\end{array}$ \\
\hline 16 & Male/51 & $\begin{array}{l}\text { Bence--Jones } \\
\text { proteinuria }\end{array}$ & $\begin{array}{l}\text { Interstitial histiocytes, } \\
\text { podocytes, mesangial cells, } \\
\text { endothelial } \\
\text { cells }\end{array}$ & $\begin{array}{l}\text { IHC: Negative for both } \kappa \text { and } \\
\lambda\end{array}$ \\
\hline 17 & Female/46 & $\begin{array}{l}\text { Renal insufficiency, } \\
\text { albuminuria }\end{array}$ & $\begin{array}{l}\text { Podocytes, tubular epithelial } \\
\text { cells, Interstitialhistiocytes }\end{array}$ & $\begin{array}{l}\text { IF: Positive for } \kappa \text {; negative } \\
\text { for } \lambda\end{array}$ \\
\hline Current case & Female/71 & Proteinuria & Podocytes & $\begin{array}{l}\text { IHC: Positive for } \kappa \text {; negative } \\
\text { for } \lambda\end{array}$ \\
\hline
\end{tabular}

sions deposited in podocytes and only 10 cases have been reported to date $(2,5,6,11-17)$ (Table). Therefore, the present case, which was identified via electron microscopy, represents the 11th case reported. At 3,000x magnification, the accumulation of large quantities of rod-like crystals in the cytoplasm of podocytes was observed.

Injuries caused by light chain deposition are due to the abnormal structure of the light chain itself, as the light chain variable region can resist proteolytic reactions mediated by tubular lysosomal enzymes, pepsin, and cathepsin B. However, the light chains present in cases of light chain cast nephropathy ( $\mathrm{LCCN}$ ) can be completely hydrolysed by these enzymes (18). It is thought that the variable region, which shows resistance to proteolysis, can spontaneously form crystals with similar shapes as renal crystals in vitro. It is therefore speculated that light chains in the blood pass through the glomerular basement membrane and into the crude urine, where they enter into cells via pinocytosis and endocytosis of podocytes. During this process of crystalloid formation, the proteolytic resistance of the light chain variable region is reduced (19), with the light chain variable region accumulating in lysosomes and spontaneously forming crystals. The reason that light chains do not form casts is because their affinity is lower than that of T-H proteins and they cannot easily accumulate in the distal tubules (18). However, it remains unclear whether the light chain is a causative factor or a manifestation of the disease, although morphological evidence for tubular damage in biopsy tissues has not revealed other significant risk factors besides light chain deposition. Moreover, animal experiments, in vitro experiments, and clinical evidence have confirmed that regardless of crystalloid formation, light chain deposition can cause damage to the kidneys $(19,20)$. Therefore, we are inclined to support the light chain pathogenic theory, as crystalloid formation due to light chain deposition in podocytes has also been shown to result in severe impairments (11).

We herein presented a case of widespread renal light chain deposition associated with the formation of intracellular crystalline inclusion bodies in podocytes secondary to multiple myeloma. The significance of these crystal structures remains unclear, but they may represent a characteristic manifestation of the disease. Moreover, if light chain deposition or crystalline inclusion bodies are found in the renal tissue of patients, the possibility of plasma cell disease should therefore be considered when making a differential diagnosis.

\section{The authors state that they have no Conflict of Interest (COI).}

\section{Financial Support}

This work was supported by Medical Science and Technology Fund for Youth of PLA, China (Grant No. 13QNP180) and Project of Chinese PLA 309 Hospital, China (2014MS-006).

Yuan-da Wang and Zhe-yi Dong contributed equally to this 
work.

\section{References}

1. Stompór T, Perkowska-Ptasińska A, Wojciechowska M, Zajac K, Chmielewska-Badziag A, Pawłowska A. Unusual manifestation of crystalline light chain tubulopathy in patient with multiple myeloma: case report and review of the literature. Ren Fail 36: 795-799, 2014.

2. Keller LS, Faull RJ, Smith P, et al. Crystalloid deposits in the kidney. Nephrology 10: 81-83, 2005.

3. Blade J, Fernandez-Llama P, Bosch F, et al. Renal failure in multiple myeloma: presenting features and predictors of outcome in 94 patients from a single institution. Arch Intern Med 158: 18891893, 1998.

4. Kyle RA. Multiple myeloma: review of 869 cases. Mayo Clin Proc 50: 29-40, 1975.

5. Nasr SH, Preddie DC, Markowitz GS, Appel GB, D'Agati VD. Multiple myeloma, nephrotic syndrome and crystalloid inclusions in podocytes. Kidney Int 69: 616-620, 2006.

6. Kowalewska J, Tomford RC, Alpers CE. Crystals in podocytes: an unusual manifestation of systemic disease. Am J Kidney Dis 42: 605-611, 2003.

7. Kapur U, Barton K, Fresco R, Leehey DJ, Picken MM. Expanding the pathologic spectrum of immunoglobulin light chain proximal tubulopathy. Arch Pathol Lab Med 131: 1368-1372, 2007.

8. Gu X, Barrios R, Cartwright J, Font RL, Truong L, Herrera GA. Light chain crystal deposition as a manifestation of plasma cell dyscrasias: the role of immunoelectron microscopy. Hum Pathol 34: 270-277, 2003.

9. Markowitz GS. Dysproteinemia and the kidney. Adv Ana Pathol 11: 49-63, 2004.

10. Larsen CP, Bell JM, Harris AA, Messias NC, Wang YHH, Walker PD. The morphologic spectrum and clinical significance of light chain proximal tubulopathy with and without crystal formation.
Modern Pathol 24: 1462-1469, 2011.

11. Akilesh S, Alem A, Nicosia RF. Combined crystalline podocytopathy and tubulopathy associated with multiple myeloma. Hum Pathol 45: 875-879, 2014.

12. Elliott MR, Cortese C, Moreno-Aspitia A, Dwyer JP. Plasma cell dyscrasia causing light chain tubulopathy without Fanconi syndrome. Am J Kidney Dis 55: 1136-1141, 2010.

13. Carstens PH, Woo D. Crystalline glomerular inclusions in multiple myeloma. Am J Kidney Dis 14: 56-60, 1989.

14. Yamamoto T, Hishida A, Honda N, Ito I, Shirasawa H, Nagase M. Crystal-storing histiocytosis and crystalline tissue deposition in multiple myeloma. Arch Pathol Lab Med 115: 351-354, 1991.

15. Matsuyama N, Joh K, Yamaguchi Y, et al. Crystalline inclusions in the glomerular podocytes in a patient with benign monoclonal gammopathy and focal segmental glomerulosclerosis. Am J Kidney Dis 23: 859-865, 1994.

16. Papla B, Spolnik P, Rzenno E, et al. Generalized crystal-storing histiocytosis as a presentation of multiple myeloma: a case with a possible pro-aggregation defect in the immunoglobulin heavy chain. Virchows Arch 445: 83-89, 2004.

17. Tomioka M, Ueki K, Nakahashi $H$, et al. Widespread crystalline inclusions affecting podocytes, tubular cells and interstitial histiocytes in the myeloma kidney. Clin Nephrol 62: 229-233, 2004.

18. Leboulleux M, Lelongt $B$, Mougenot $B$, et al. Protease resistance and binding of Ig light-chains in myeloma-associated tubulopathies. Kidney Int 48: 72-79, 1995.

19. Sengul S, Zwizinski C, Simon EE, Kapasi A, Singhal PC, Batuman V. Endocytosis of light chains induces cytokines through activation of NF- $\mathrm{KB}$ in human proximal tubule cells. Kidney Int 62: 1977-1988, 2002.

20. Sanders PW, Herrera GA, Galla JH. Human Bence Jones protein toxicity in rat proximal tubule epithelium in vivo. Kidney Int 32: 851-861, 1987.

(C) 2016 The Japanese Society of Internal Medicine http://www.naika.or.jp/imonline/index.html 